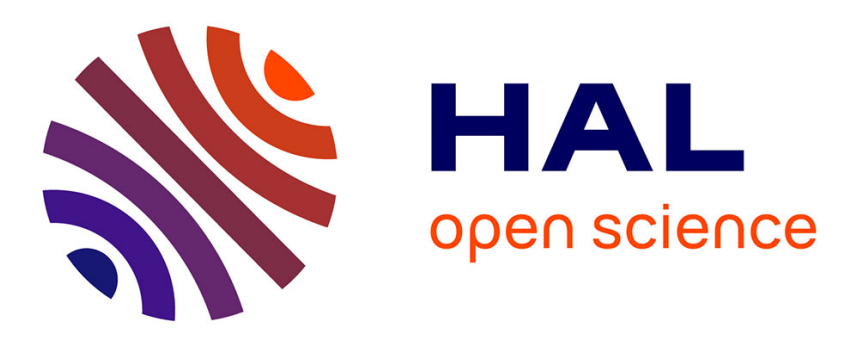

\title{
Tank bromeliads sustain high secondary production in neotropical forests
}

\author{
Olivier Dézerald, Céline Leroy, Bruno Corbara, Alain Dejean, Stanislas \\ Talaga, Régis Céréghino
}

\section{- To cite this version:}

Olivier Dézerald, Céline Leroy, Bruno Corbara, Alain Dejean, Stanislas Talaga, et al.. Tank bromeliads sustain high secondary production in neotropical forests. Aquatic Sciences - Research Across Boundaries, 2018, 80 (2), 10.1007/s00027-018-0566-3 . hal-01850394

\section{HAL Id: hal-01850394 \\ https://hal.umontpellier.fr/hal-01850394}

Submitted on 11 Jul 2019

HAL is a multi-disciplinary open access archive for the deposit and dissemination of scientific research documents, whether they are published or not. The documents may come from teaching and research institutions in France or abroad, or from public or private research centers.
L'archive ouverte pluridisciplinaire HAL, est destinée au dépôt et à la diffusion de documents scientifiques de niveau recherche, publiés ou non, émanant des établissements d'enseignement et de recherche français ou étrangers, des laboratoires publics ou privés. 


\title{
Tank bromeliads sustain high secondary production in neotropical forests
}

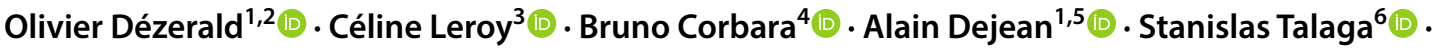 \\ Régis Céréghino ${ }^{5}$
}

Received: 30 August 2017 / Accepted: 16 January 2018

(c) Springer International Publishing AG, part of Springer Nature 2018

\begin{abstract}
In neotropical landscapes, a substantial fraction of the still waters available is found within tank bromeliads, plants which hold a few milliliters to several litres of rainwater within their leaf axils. The bromeliad ecosystem is integrated into the functioning of rainforest environments, but no study has ever estimated the secondary production, nor the biomass turnover rates of bromeliad macroinvertebrates in relation to other functional traits. We estimated secondary production at invertebrate population to metacommunity level in bromeliads of French Guiana. Coleoptera, Diptera and Crustacea with traits that confer resistance to drought had lower biomass turnover, longer generation times, and slower individual growth than species without particular resistance traits, suggesting convergent life history strategies in phylogenetically distant species. Detritivores and predators accounted for $87 \%$ and $13 \%$ of the overall annual production, respectively, but had similar production to biomass ratios. An average bromeliad sustained a production of $23.93 \mathrm{~g}_{\text {dry }}$ mass $\mathrm{m}^{-2} \mathrm{year}^{-1}$, a value which exceeds the medians of 5.0-14.8 $\mathrm{g} \mathrm{DM} \mathrm{m}^{-2}$ year $^{-1}$ for lakes and rivers worldwide. Extrapolations to the total water volumes held by bromeliads at our field site yielded secondary production estimates of $226.8 \pm 32.5 \mathrm{~g} \mathrm{DM} \mathrm{ha}^{-1} \mathrm{year}^{-1}$. We conclude that the ecological role of tank bromeliads in neotropical rainforests may be as important as that of other freshwater ecosystems.
\end{abstract}

Keywords Biomass turnover $\cdot$ Epiphytes $\cdot$ Functional traits $\cdot$ Food webs $\cdot$ Invertebrates $\cdot$ Rainforests

Electronic supplementary material The online version of this article (https://doi.org/10.1007/s00027-018-0566-3) contains supplementary material, which is available to authorized users.

Olivier Dézerald

olivier.dezerald@gmail.com

1 CNRS, UMR Ecologie des Forêts de Guyane (AgroParisTech, CIRAD, INRA, Université des Antilles, Université de Guyane), Campus Agronomique, 97379 Kourou cedex, France

2 Present Address: Université de Lorraine, UMR Laboratoire Interdisciplinaire des Environnements Continentaux (CNRS), Campus Bridoux, 57070 Metz, France

3 AMAP, IRD, CNRS, INRA, Université Montpellier, Montpellier, France

4 Université Clermont Auvergne, CNRS, LMGE, 63000 Clermont-Ferrand, France

5 Ecolab, Laboratoire Ecologie Fonctionnelle et Environnement, Université de Toulouse, CNRS-UPS-INPT, 118 route de Narbonne, 31062 Toulouse, France

6 Université de Guyane, UMR Écologie des Forêts de Guyane (AgroParisTech, CIRAD, CNRS, INRA, Université des Antilles), Campus Agronomique, BP 316, 97379 Kourou cedex, France

\section{Introduction}

Neotropical landscapes have not been scoured by glaciers, and therefore contain much fewer lakes than their temperate counterparts. Instead, a substantial fraction of still waters available to the freshwater fauna is found within phytotelmata ("plant-held waters", e.g., tree holes, pitcher plants, tank bromeliads) that form freshwater islands in a terrestrial matrix. Bromeliads (Bromeliaceae) are flowering plants represented by 3,140 species, native to the Neotropics (Givnish et al. 2011). The leaves of tank bromeliads are tightly interlocking, forming wells that collect rainwater and leaf litter. These reservoirs hold a few milliliters to $45 \mathrm{Ls}$ of water (Benzing 2000) and provide a habitat for aquatic organisms ranging from prokaryotes to macroinvertebrates (Brouard et al. 2012; Frank and Lounibos 2009) and occasionally vertebrates (e.g., frogs, snakes; Poelman et al. 2013). In rainforests, tank bromeliads occur from the soil to the canopy (as epiphytes) and can reach a density of up to 175,000 individuals per hectare and impound up to 50,000 Ls of water per hectare (Richardson 1999). The incoming detritus (e.g., 
leaf litter, dead arthropods, feces) constitutes a source of nutrients for the aquatic food web and for the plant itself (Benzing 2000; Leroy et al. 2016). Macroinvertebrates, mostly aquatic insect larvae, make up the dominant part of the animal biomass. A handful of studies have estimated the invertebrate biomass found in tank bromeliads (Petermann et al. 2015; Richardson et al. 2005). Nevertheless, these measurements represent snapshots in time (Stork and Eggleton 1992) whereas seasonal changes in relation to population dynamics can be significant (Dézerald et al. 2017). In other words, occasional biomass and/or density estimates tell us little about turnover times of invertebrate populations, or about the relationships between community structure and ecosystem processes in tank bromeliads.

Despite their abundance across the neotropics, no previous study has ever estimated the annual secondary production of macroinvertebrates sustained by tank bromeliads, nor, perhaps more importantly, the biomass turnover rates of such bromeliad-dwelling organisms. Secondary production, the formation of heterotrophic biomass per unit surface area (or unit volume) per unit time, is a measurement of the carbon and energy flow in ecosystems when estimated at the scale of a community (Benke and Wallace 2014). Secondary production estimates encompass information on population density, growth rates and biomass turnover times, and, therefore, constitute an accurate way of quantifying (2) the proportion of energy flow mediated by each species within food webs (Benke et al. 1984), and (2) the importance of various habitat types in contributing animal biomass to their larger environment (Gratton and Vander Zanden 2009). A species biomass turnover rate, or production-to-biomass ratio (P:B, the annual production divided by the mean annual biomass over the entire year), is negatively correlated with its lifespan and increases with the number of generations per year. Together with other functional traits (e.g., trophic habits, locomotion mode, resistance to drought), production-related statistics (e.g., growth, biomass, turnover rates, larval life span, and number of generations per year) form trait syndromes common to species that respond in a similar way to the same environmental filters (Gamez-Virues et al. 2015). These syndromes can therefore be used to predict population to community level responses to the dynamics of their habitat (e.g., food and habitat resources; Pianka 1970). Information on secondary production and biomass turnover is of critical importance to any effort to predict ecosystem responses to environmental fluctuations, be they natural or anthropogenic.

Both observational studies and short-term experiments (Ngai and Srivastava 2006; Richardson et al. 2000b) suggest that the bromeliad ecosystem is tightly integrated into the structure and functioning of its rainforest environment (e.g., processing of incoming detritus, emergence of adult insects that feed terrestrial predators). Because we lack an even basic understanding of how bromeliad-associated fauna contributes to energy flows in rainforests, the quantification of invertebrate production from the individual bromeliad to the level of a forest plot and its partitioning into invertebrate functional groups may help in estimating the ecological importance of plant-held waters within rainforest environments. In this study, we estimated the annual production and $\mathrm{P}: \mathrm{B}$ of the aquatic invertebrates inhabiting a tank-bromeliad species commonly found in rainforests of French Guiana. Annual production was further estimated for functional feeding groups, the entire community of an "average bromeliad", and at the scale of a hectare of forest. We then used these estimates to ask two fundamental questions. First, is the secondary production of the various invertebrate species associated to particular suites of functional traits? For instance, those species with low P:B (denoting longer generation time) could share traits that imply higher energetic costs (e.g., construction of a sclerotized exoskeleton). In contrast, invertebrates with high P:B could display cost-effective traits (e.g., soft bodies). Second, is the secondary production sustained by tank bromeliads similar to the secondary production found in other aquatic systems worldwide? The literature we reviewed showed no evidence that secondary production relates to habitat size, nor to geographic regions (Gratton and Vander Zanden 2009). Therefore, for a fixed surface area, we did not expect secondary production in water-filled bromeliads to be different from that of larger freshwater systems elsewhere. Owing to the ubiquity and density of tank bromeliads in the neotropics, we further discuss their ecological role in neotropical forests.

\section{Materials and methods}

\section{Study area and bromeliad species}

Our study was conducted in French Guiana in a lowland rainforest typical of the Guyana Shield (north-eastern coast of South America), the epicenter of bromeliad radiation (Givnish et al. 2011). The studied area $\left(c a .5,000 \mathrm{~m}^{2}\right)$ was located near the Petit-Saut Dam, Sinnamary $\left(5^{\circ} 03^{\prime} 43^{\prime \prime} \mathrm{N}\right.$, $53^{\circ} 02^{\prime} 46^{\prime \prime} \mathrm{W}$; elevation $<80 \mathrm{~m}$ a.s.1.). The climate is tropical moist with $3000 \mathrm{~mm}$ of annual precipitation, little seasonal variation in air temperature (monthly averages range from 20.5 to $33.5^{\circ} \mathrm{C}$ ), and a relative humidity oscillating between 70 and $100 \%$. There is a major reduction in rainfall between September and November and a short and irregular dry period in March, but overall prolonged absence of rainfall is rare; a maximum of $17 \pm 5( \pm \mathrm{SE})$ consecutive days without rainfall were recorded, on average, over the past 10 years (Dézerald et al. 2015). Several species of bromeliads cooccur regionally in French Guiana (Dézerald et al. 2013; Leroy et al. 2017), but not necessarily locally. Here, Vriesea 
splendens (Brongn.) Lem. (Bromeliaceae, Tillandsioideae) was the only tank bromeliad at our study site (Fig. 1).

\section{Sampling procedure}

We sampled three well-developed $V$. splendens (excluding flowering and immature stages) twice per month, from April 2013 to April 2014, for a total of 72 plants (each group of three plants was sampled only once). Selected plants were epiphytes growing at $<1 \mathrm{~m}$ above the ground or were rooted on the soil. We first extracted, from the rosette of each plant, all of the coarse ( $>1000 \mu \mathrm{m}$ in size) detritus fallen from overhanging trees (e.g., leaf litter, twigs) and rinsed them in the field to collect any associated invertebrates. To sample the water and aquatic invertebrates in the plants, we used a 10-ml micropipette with the end trimmed to widen the aperture. We measured the actual volume $(\mathrm{V}, \mathrm{ml})$ using a 250-ml graduated cylinder for the first water extraction; the wells were then refilled with rainwater and emptied again

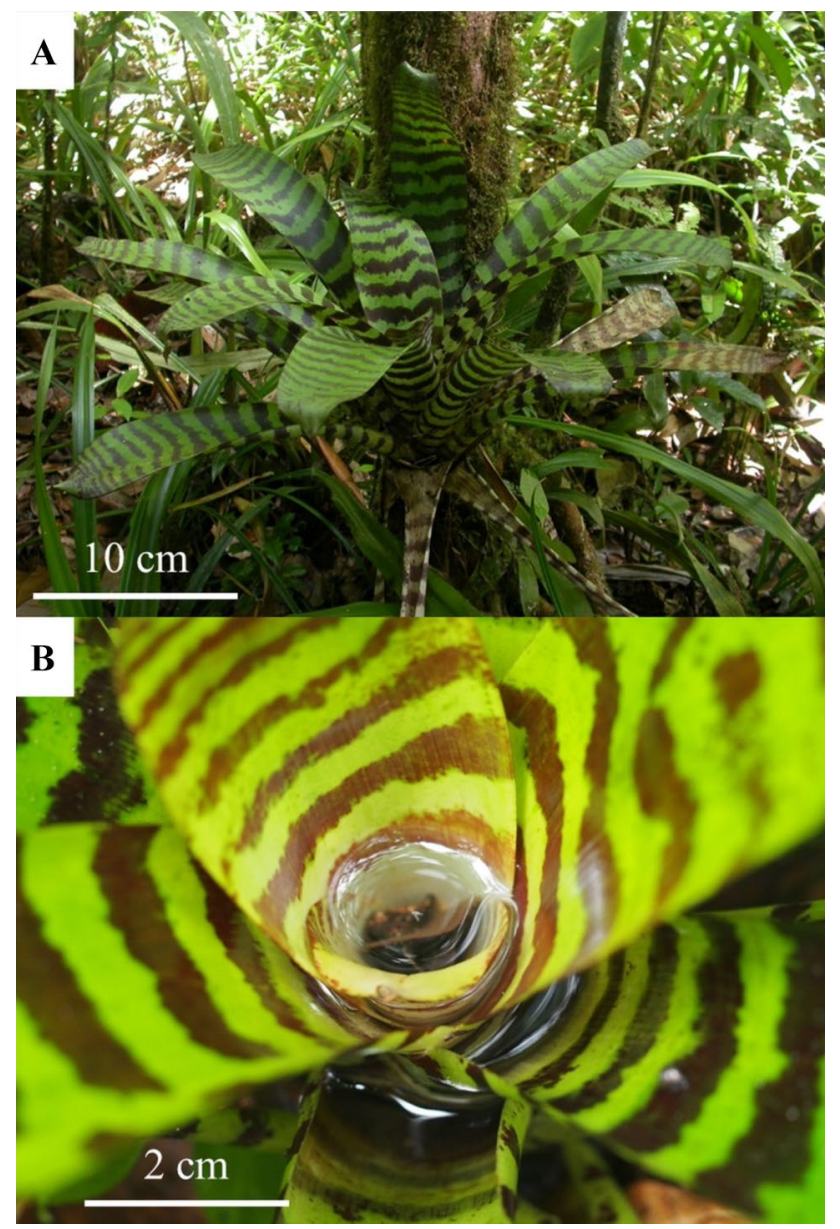

Fig. 1 Photographs of a medium-sized Vriesea splendens found at our study site in French Guyana, and b the central and lateral wells containing rainwater and leaf litter. Photo credit: Bruno Corbara twice in order to maximize invertebrate sampling efficiency. We filtered the sampled water through a $150-\mu \mathrm{m}$ mesh and preserved the aquatic invertebrates in $4 \%$ formalin (final concentration). Once a plant was emptied, we measured its maximum water volume (Vmax, $\mathrm{ml}$ ) as the difference between a known volume of water used to fill the bromeliad and the remaining water volume in the graduated cylinder when the bromeliad overflowed. We used this nondestructive sampling technique both for ethical reasons and for consistency with other studies in the area (Céréghino et al. 2011; Dézerald et al. 2013). To ensure, however, that this technique did not generate biases in species abundance estimates (especially for those rare top predators that crawl down the leaves), we also dissected a different set of 30 plants and compared the average abundances of these taxa in each dissected plant with their abundances in undissected ones. We found no significant differences between the two methods (Appendix S1). We have also demonstrated that the sampling of three different plants every two weeks efficiently captures the natural dynamics of bromeliad invertebrate meta-populations (see Dézerald et al. 2017).

\section{Secondary production estimates of bromeliad invertebrates}

Aquatic invertebrates were identified to species or morphospecies (hereafter, "species"), enumerated, and preserved in $70 \%$ ethanol (Table 1). All larvae were divided into $0.1 \mathrm{~mm}$ interval size classes based on measurements of non-deformable body parts (i.e., head capsule width and length, or carapace length depending on the species). Measurements were used to identify the larval instars. For each species, 20 individuals from the different size classes or larval instars were dried at $60^{\circ} \mathrm{C}$ for $48 \mathrm{~h}$ and weighed with an electronic balance $( \pm 0.1 \mu \mathrm{g})$. We used the maximum water volume (Vmax) of the plant to calculate densities (D, ind. $\mathrm{ml}^{-1}$ ), biomasses ( $\mathrm{B}, \mathrm{mg}$ dry mass $\mathrm{ml}^{-1}$ ), and secondary production ( $\mathrm{mg}$ dry mass $\mathrm{ml}^{-}$year ${ }^{-1}$ ), because the actual volume $(\mathrm{V})$ is too sensitive to daily or even hourly changes in rainfall. We noted that the sampled bromeliads were filled to $c a$. $50 \%$ of their maximum volume $(\mathrm{V} / \mathrm{Vmax}=51.8 \pm 0.06 \%)$ throughout the year. By using Vmax to calculate densities and biomasses (a "dilution" of the number of individuals found in $\mathrm{V}$ ), we provide conservative values for subsequent estimates of secondary production.

We used the size-frequency method (Babler et al. 2008; Benke and Wallace 2014; Hynes and Coleman 1968; Stead et al. 2005) to obtain estimates of secondary production from life history, density and biomass data (see Dézerald et al. 2017). We used this method since it evaluates the size-frequency structure of a given population from field samples taken at different times during the observation period. Although various methods exist for evaluating 
Table 1 Population statistics of aquatic invertebrates in the studied tank bromeliad

\begin{tabular}{|c|c|c|c|c|c|c|}
\hline Taxa & $\mathrm{D}$ & $\mathrm{B}$ & $P$ & P:B & Boot-P:B & $95 \% \mathrm{CI}$ \\
\hline \multicolumn{7}{|l|}{ Diptera } \\
\hline \multicolumn{7}{|l|}{ Culicidae } \\
\hline Wyeomyia aphobema & $1.8 \mathrm{e}-1 \pm 2.8 \mathrm{e}-2$ & $7.2 \mathrm{e}-3 \pm 1.2 \mathrm{e}-3$ & $1.4 \mathrm{e}-1$ & 35.0 & 35.9 & $23.4-57.7$ \\
\hline Wyeomyia lamellata & $8.3 e-2 \pm 1.1 e-2$ & $3.7 e-3 \pm 6.5 e-4$ & $2.3 e-2$ & 10.0 & 12.7 & $6.4-22.0$ \\
\hline Wyeomyia robusta & $2.0 \mathrm{e}-3 \pm 1.4 \mathrm{e}-3$ & $9.3 e-5 \pm 6.7 e-5$ & $2.5 \mathrm{e}-3^{\mathrm{a}}$ & $26.7^{\mathrm{a}}$ & - & - \\
\hline Culex stonei & $3.0 \mathrm{e}-2 \pm 8.0 \mathrm{e}-3$ & $1.1 \mathrm{e}-3 \pm 2.2 \mathrm{e}-4$ & $7.0 \mathrm{e}-3$ & 10.4 & 12.8 & $1.8-32.5$ \\
\hline Anopheles neivai & $2.3 e-2 \pm 6.6 e-3$ & $1.3 e-3 \pm 2.9 e-4$ & $1.5 \mathrm{e}-2$ & 72.0 & 69.5 & $13.4-101.5$ \\
\hline Toxorhynchites haemorrhoidalis & $4.9 e-4 \pm 6.5 e-4$ & $1.7 \mathrm{e}-4 \pm 2.2 \mathrm{e}-4$ & $3.8 \mathrm{e}-3^{\mathrm{a}}$ & $23.1^{\mathrm{a}}$ & - & - \\
\hline \multicolumn{7}{|l|}{ Corethrellidae } \\
\hline Corethrella sp & $1.4 \mathrm{e}-1 \pm 9.4 \mathrm{e}-3$ & $3.3 \mathrm{e}-3 \pm 2.0 \mathrm{e}-4$ & $3.5 \mathrm{e}-2^{\mathrm{a}}$ & $10.7^{\mathrm{a}}$ & - & - \\
\hline \multicolumn{7}{|l|}{ Ceratopogonidae } \\
\hline Bezzia sp & $1.2 \mathrm{e}-1 \pm 1.6 \mathrm{e}-2$ & $2.4 e-3 \pm 4.2 e-4$ & $3.0 \mathrm{e}-2$ & 11.8 & 12.7 & $10.2-15.8$ \\
\hline Ceratopogonidae sp.1 & $3.5 \mathrm{e}-2 \pm 1.1 \mathrm{e}-2$ & $2.6 e-4 \pm 8.9 e-5$ & $4.7 e-3$ & 16.1 & 15.2 & $10.7-20.8$ \\
\hline Ceratopogonidae sp.2 & $5.2 e-4 \pm 6.3 e-4$ & $6.8 \mathrm{e}-6 \pm 8.3 \mathrm{e}-6$ & $3.6 \mathrm{e}-4^{\mathrm{a}}$ & $52.4^{\mathrm{a}}$ & - & - \\
\hline Ceratopogonidae sp.3 & $3.6 e-4 \pm 3.6 e-4$ & $4.8 \mathrm{e}-6 \pm 4.8 \mathrm{e}-6$ & $2.7 \mathrm{e}-4^{\mathrm{a}}$ & $57.4^{\mathrm{a}}$ & - & - \\
\hline \multicolumn{7}{|l|}{ Chironomidae } \\
\hline Orthocladiinae sp & $1.8 \mathrm{e}-2 \pm 3.1 \mathrm{e}-3$ & $5.7 e-5 \pm 1.7 e-5$ & $3.0 \mathrm{e}-3$ & 45.5 & 45.5 & $32.0-64.8$ \\
\hline Tanypodinae sp & $9.0 e-4 \pm 8.4 e-4$ & $3.6 e-5 \pm 3.4 e-5$ & $1.2 \mathrm{e}-3^{\mathrm{a}}$ & $34.1^{\mathrm{a}}$ & - & - \\
\hline Tanytarsini sp & $3.2 \mathrm{e}-4 \pm 3.9 \mathrm{e}-4$ & $2.5 e-5 \pm 3.1 e-5$ & $9.5 \mathrm{e}-4^{\mathrm{a}}$ & $37.3^{\mathrm{a}}$ & - & - \\
\hline \multicolumn{7}{|l|}{ Tipulidae } \\
\hline Trentepohlia sp & $6.3 e-2 \pm 6.3 e-3$ & $8.4 e-3 \pm 9.5 e-4$ & $7.4 e-2$ & 10.5 & 10.6 & $7.6-14.1$ \\
\hline \multicolumn{7}{|l|}{ Psychodidae } \\
\hline Telmatoscopus sp & $3.6 e-4 \pm 2.8 e-4$ & $2.9 e-5 \pm 2.3 e-5$ & $1.0 \mathrm{e}-3^{\mathrm{a}}$ & $36.1^{\mathrm{a}}$ & - & - \\
\hline Brachycera spp & $1.6 \mathrm{e}-2 \pm 2.6 \mathrm{e}-3$ & $5.1 \mathrm{e}-4 \pm 8.4 \mathrm{e}-5$ & $8.8 \mathrm{e}-3^{\mathrm{a}}$ & $17.3^{\mathrm{a}}$ & - & - \\
\hline \multicolumn{7}{|l|}{ Odonata } \\
\hline \multicolumn{7}{|l|}{ Coenagrionidae } \\
\hline Coenagrionidae $\mathrm{sp}$ & $4.9 e-4 \pm 3.7 e-4$ & $2.4 \mathrm{e}-5 \pm$ & $9.2 \mathrm{e}-4^{\mathrm{a}}$ & $37.7^{\mathrm{a}}$ & - & - \\
\hline \multicolumn{7}{|l|}{ Coleoptera } \\
\hline \multicolumn{7}{|l|}{ Scirtidae } \\
\hline Cyphon sp & $2.8 \mathrm{e}-1 \pm 2.7 \mathrm{e}-2$ & $2.8 \mathrm{e}-2 \pm 3.4 \mathrm{e}-3$ & $2.1 \mathrm{e}-1$ & 6.3 & 6.0 & $5.2-6.8$ \\
\hline \multicolumn{7}{|l|}{ Podocopida } \\
\hline \multicolumn{7}{|l|}{ Limnocytheridae } \\
\hline Elpidium bromeliarum & $7.1 e-1 \pm 9.5 e-2$ & $1.3 e-3 \pm 1.7 e-4$ & $1.8 \mathrm{e}-2^{\mathrm{a}}$ & $13.6^{\mathrm{a}}$ & - & - \\
\hline \multicolumn{7}{|l|}{ Haplotaxida } \\
\hline \multicolumn{7}{|l|}{ Naididae } \\
\hline Aulophorus superterrenus & $1.3 e-1 \pm 3.5 e-2$ & $5.4 e-3 \pm 1.5 e-3$ & $5.1 \mathrm{e}-2^{\mathrm{a}}$ & $9.4^{\mathrm{a}}$ & - & - \\
\hline \multicolumn{7}{|l|}{ Hemiptera } \\
\hline \multicolumn{7}{|l|}{ Veliidae } \\
\hline Paravelia sp & $6.7 e-4 \pm 4.7 e-4$ & $7.2 \mathrm{e}-4 \pm 5.0 \mathrm{e}-4$ & $1.1 \mathrm{e}-2^{\mathrm{a}}$ & $15.8^{\mathrm{a}}$ & - & - \\
\hline
\end{tabular}

- indicate that the CPI could not be obtained

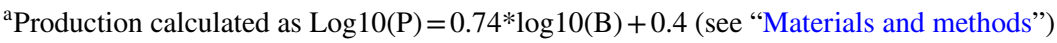

$D$ mean annual density $\pm \mathrm{SE}$ (ind $\left.\mathrm{ml}^{-1}\right), B$ mean annual biomass $\pm \mathrm{SE}\left(\mathrm{mg} \mathrm{ml}^{-1}\right), P$ and $P: B$ annual production $\left(\mathrm{mg} \mathrm{ml}^{-1}\right.$ year $\left.{ }^{-1}\right)$ and production-to-biomass ratios, Boot-P:B and $95 \%$ CI bootstrapped median of production-to-biomass ratio and $95 \%$ confidence interval (see text)

production estimates (e.g., Allen curve, instantaneous growth, increment summation, regressions), the size-frequency method is the only one that allows integrating the natural dynamics of the system (i.e., processes of colonization and emergence), while providing a conservative estimate of secondary production (Benke and Wallace 2014; Morin et al. 1987). This method thus contrasts with other methods that follow the production of one single cohort through time (Morin et al. 1987). Cohorts, sensu stricto, are groups of individuals sharing the same 
hatching event during a particular time span. As for most life history studies, we corrected the densities of all size classes to control for differences in the time spent among these size classes (Benbow et al. 2003; Perán et al. 1999; Appendix S2). Cohort production and annual production ( $\mathrm{Pc}$ and $\mathrm{P}$, respectively, in $\mathrm{mg} \mathrm{DM} \mathrm{ml}^{-1}$ year $^{-1}$ ) were calculated as follows:

$P c=i \cdot \sum_{j=1}^{i}\left[(N \mathrm{j}-N \mathrm{j}+1) \cdot \frac{1}{2} \cdot(D M \mathrm{j}+D M \mathrm{j}+1)\right]$

and

$\mathrm{P}=P c \cdot\left(\frac{365}{\mathrm{CPI}}\right)$

where $i$ is the number of size classes, $\mathrm{N} j$ is the mean corrected number of individuals in a size class $(j)$ during the year, $\mathrm{DMj}$ is the mean individual dry mass of a size class $(j)$. Cohort production interval (CPI, the number of days from hatching to the final size class) was taken from a companion study where we described the life cycle patterns (e.g., cohorts) of the study species (Dézerald et al. 2017). In order to assess the reliability of our size frequency-based secondary production estimates, we performed a bootstrap procedure to account for variability in those estimates (Babler et al. 2008). We generated bootstrap replicates of $P: B$ ratio estimates by randomly reassembling 1000 data sets with replacement from the original data set. Because the community structure can potentially change over time (Dézerald et al. 2017), we constrained the bootstrapped procedure to randomly sample data by sampling date. Subsequently, the median, 2.5 and $97.5 \%$ percentiles from the 1,000 bootstrapped $\mathrm{P}: \mathrm{B}$ ratios were presented for each species.

The size-frequency method was used for the dominant taxa (together making up $>90 \%$ of mean annual biomass). This method, however, yielded negative production values for Corethrella sp. and Elpidium bromeliarum, even after correcting for the number of individuals within size classes. Such a case can happen when no biomass loss occurs between successive size classes (Babler et al. 2008; Huryn 1990; Stead et al. 2005). To calculate the annual production of these two taxa and those rare species whose CPI could not be obtained (11 species, altogether $<10 \%$ of the mean annual biomass), we first regressed the log-transformed annual production against the log-transformed annual biomass of the species for which we described the life cycles (using the size-frequency method), and then used the resulting linear model $\log (\mathrm{P})=0.74 \log (\mathrm{B})+0.04\left(\mathrm{R}^{2}=0.89, P=0.0001\right)$ to estimate $\mathrm{P}$ from $\mathrm{B}$. This relationship between $\log (\mathrm{P})$ and $\log (B)$ has already been estimated in another aquatic invertebrate communities with strikingly similar slope estimate (slope $=0.79$; Benke and Huryn 2010; Plante and Downing 1989). Finally, production estimates were also partitioned into trophic levels (detritivores or predators), and into invertebrate functional feeding groups (FFGs sensu Merritt et al. 2008). The various species were assigned to FFGs based on feeding modes and gut content analyses (Dézerald et al. 2013). Differences in the distribution of production statistics between detritivores and predators were evaluated with Mann-Whitney tests.

\section{Trait syndromes}

To explore relationships between production-related statistics and other functional traits of invertebrates (i.e., mixture of continuous and categorical variables), we performed a mixed Principal Component Analysis (mPCA) on the 11 dominant species and their functional traits. The mean individual growth rate (k, \% day ${ }^{-1}$; after Dézerald et al. 2017), mean cohort production interval (CPI, days), mean annual biomass $\left(\mathrm{B}, \mathrm{mg} \mathrm{ml}^{-1}\right)$, annual production $\left(\mathrm{P}, \mathrm{mg} \mathrm{ml}^{-1}\right.$ year $\left.^{-1}\right)$, biomass turnover rate (P:B ratio), and body size formed a first set of continuous variables that were ranktransformed. Locomotion (swimmer or crawler; hereafter), respiration mode (tegument/gills or plastron/respiratory siphon), body armor (soft bodied or sclerotized/shell), and trophic levels (detritivore or predator) were categorical variables with two levels each. The mPCA was conducted using the ade4-package in $\mathrm{R}$ (Chessel et al. 2004).

\section{Broadening the scale: from individual bromeliads to forest plots}

Vriesea splendens bromeliads were arbitrarily divided into four size classes based on plant width (PW): "tankless" (i.e., immature individuals), "small" ( $\mathrm{PW}<20 \mathrm{~cm}$, $\mathrm{V} \max =30.4 \pm 2.1 \mathrm{ml})$, "medium" $(\mathrm{PW}=20-40 \mathrm{~cm}$, $V \max =100.1 \pm 3.2 \mathrm{ml})$, and "large" $(\mathrm{PW}>40 \mathrm{~cm}$, $\mathrm{V} \max =234.21 \pm 10.1 \mathrm{ml})$. Mean $\mathrm{Vmax}( \pm \mathrm{SE})$ were measured for 30 plants in each size class. We used secondary production estimates for each invertebrate species to estimate the annual production of the invertebrate community found in an "average" $V$. splendens of the largest size class, because this class contributes $\sim 55 \%$ of the total amount of water held by all tank bromeliads in a hectare of forest (see results).

The annual production values of all invertebrate species per $\mathrm{ml}$ were summed up and multiplied by $234 \mathrm{ml}$, the Vmax of an "average" $V$. splendens of the largest size class. The secondary production of an individual $V$. splendens bromeliad was assigned to the surface area of the water surface delineated by all leaves forming wells. Bromeliad leaves are arranged in rosettes, so the water surface delineated by one well is approximately a semicircular area (except for the 
central well, which is a full circle area), with a radius equal to $1.9 \pm 0.1 \mathrm{~cm}($ mean $\pm \mathrm{SE}, \mathrm{n}=30)$, we multiplied this surface area by the mean number of wells $(10.48 \pm 0.34$ wells or 11 semicircle areas for an average bromeliad; $\pm \mathrm{SE}, \mathrm{n}=30$ ) to obtain the total water surface area of the tank bromeliad $\left(0.00624 \mathrm{~m}^{2}\right)$. The transformation of secondary production estimates from $\mathrm{mg} \mathrm{DM} \mathrm{ml}{ }^{-1}$ year $^{-1}$ to $\mathrm{g} \mathrm{DM} \mathrm{m}^{-2}$ year $^{-1}$ was needed to compare our values to those values provided in studies in lakes, ponds, and streams.

The $V$. splendens were unevenly distributed in the forest. To estimate their density, we first delineated three $50 \times 100 \mathrm{~m}$ plots in our study area. Then, within a given plot, we delineated four $10 \times 10 \mathrm{~m}$ quadrats evenly distributed along a $100 \mathrm{~m}$-long transect located in the middle of each plot (total number of quadrats $=12$ ). Bromeliad density was estimated by counting the number of plants within each quadrat. Their elevation above ground was measured using a laser distance meter (Leica DISTO ${ }^{\text {TM }}$ D5). The maximum elevation in the supporting trees was $11.5 \mathrm{~m}$, so we were confident that most if not all $\mathrm{V}$. splendens were visible and could be counted. The total amount of water held in plants at the scale of a quadrat was obtained by multiplying the average volume of each size class by the total number of plants within the same size class per quadrat. Assuming that all aquatic species can be found in all bromeliad size classes (except E. bromeliarum, Aulophorus superterrenus and an extremely rare odonate that were absent from the "small" bromeliads; personal obs.), secondary production was estimated at the scale of an hectare by multiplying our estimate of community-level annual production in mg DM $\mathrm{ml}^{-1}$ year $^{-1}$ by the total amount of water held by bromeliads in an average quadrat, rescaled to an hectare (multiplied by 100). Here, the transformation of estimates to $\mathrm{g} \mathrm{DM} \mathrm{m}^{-2}$ year ${ }^{-1}$ could not be made because we did not estimate the surface area of small- and medium-sized bromeliads.

In the absence of secondary production estimates for epiphyte-associated invertebrates in rainforests, we compared our results to a literature review of secondary production in freshwater systems distributed worldwide (Appendix S3). Our literature review consisted in an update of the review provided by Gratton and Vander Zanden (2009). We searched for additional (notably recent) references using combinations of the following keywords in Thompson Reuters' Web of Science®: "secondary production"; "freshwater*"; "invertebrate*"; "macroinvertebrate*"; "lake*"; "river*"; "stream*". We targeted annual production estimates for entire or the dominant groups (e.g., taxa, functional guilds) in macroinvertebrate communities in still or running waters. We thus added 26 studies and 48 production estimates to the 34 studies and 112 estimates listed in Gratton and Vander Zanden (2009) (Appendix S3). To compare our estimate of secondary production in bromeliads to estimates for other freshwater systems (on a per surface basis), we related it to the cumulative distribution of freshwater estimates grouped together and then split by ecosystem type (i.e., lakes, streams). Since freshwater estimates followed a Gamma distribution, we first used the fitdistr-function (MASS-package) to estimate the ratio and shape parameters of that distribution and then used the pgamma-function (stats-package) in R. All statistical analyses in this study were conducted using the $\mathrm{R}$ software version 3.1.2 (R Core Team 2015) and evaluated using a 95\% confidence level.

\section{Results}

\section{Secondary production estimates of bromeliad invertebrates}

The invertebrate species pool in the study area comprised a total of 22 species (see Dézerald et al. 2017). The 11 dominant species represented $89.1 \%$ of the mean annual biomass of the system. This number reached $98.3 \%$ if we include A. superterrenus (a naidid worm) and Brachycera spp. (many unidentified fly larvae). In rank order, the most productive species were the coleopteran Cyphon sp. $(0.21 \mathrm{mg}$ $\mathrm{DM} \mathrm{ml} \mathrm{m}^{-1}$ year $^{-1}$ ) and the dipterans Wyeomyia aphobema (0.14 mg DM ml ${ }^{-1}$ year $\left.^{-1}\right)$, Trentepohlia $\mathrm{sp} .(0.07 \mathrm{mg}$ $\mathrm{DM} \mathrm{ml}^{-1}$ year $^{-1}$; Table 1$)$, and Corethrella $\mathrm{sp} .(0.04 \mathrm{mg}$ $\mathrm{DM} \mathrm{ml}^{-1}$ year ${ }^{-1}$ ). With its long generation time and low individual mass, the ostracod E. bromeliarum exhibited an intermediate secondary production $\left(6.8 \mathrm{e}-3 \mathrm{mg} \mathrm{DM} \mathrm{ml}^{-1}\right.$ year $\left.^{-1}\right)$, although it was the most abundant species $(0.71$ ind. $\mathrm{ml}^{-1}$ on average). Cyphon sp. had the lowest turnover ratios $(\mathrm{P}: \mathrm{B}=6.3)$, compared to the other species $(\mathrm{P}: \mathrm{B}=10$ to 57; Table 1). Overall, the medians of 1,000 bootstrapped $\mathrm{P}: \mathrm{B}$ ratios confirmed the $\mathrm{P}: \mathrm{B}$ estimates obtained through the size-frequency method.

Detritivores and predators accounted for $87 \%$ and $13 \%$ of the overall production, and $90 \%$ and $10 \%$ of the mean annual biomass, respectively. The dominant predator in terms of production was Corethrella sp. (other predators species were Bezzia sp., Toxorhynchites haemorrhoidalis, Tanypodinae sp., Paravelia sp., and an unidentified Coenagrionidae odonate). Among the detritivores, scrapers (Cyphon sp. and E. bromeliarum) and filter feeders (Culicidae species) accounted for 35 and $29 \%$ of the annual production, respectively. Shredders (Trentepohlia sp., Telmatoscopus sp.) and collector-gatherers (the remaining species; Table 1) represented about $12 \%$ and $11 \%$ of the annual production, respectively. There were no significant differences between the distributions of production estimates, mean annual biomasses, and $\mathrm{P}: \mathrm{B}$ ratios between detritivores and predators (Mann-Whitney tests; $\mathrm{W}_{\mathrm{P}}=45, P_{\mathrm{P}}=0.86 ; \mathrm{W}_{\mathrm{B}}=42, P_{\mathrm{B}}=$ $0.69 ; \mathrm{W}_{\mathrm{P}: \mathrm{B}}=45, P_{\mathrm{P}: \mathrm{B}}=0.86$ ). 


\section{Trait syndromes}

Overall, correlations between production-related statistics and functional traits that confer in situ resistance to hydrological fluctuations in bromeliads highlighted trade-offs in life history strategies. The first three axes of the mPCA explained $79.0 \%$ of the total variance in species traits (35.6, 26.0, and $17.3 \%$ for Axis 1, 2, and 3, respectively; Fig. 2). The correlations between production-related statistics and other functional traits revealed two distinct trait syndromes along the first axis. Axis 1 was negatively correlated with generation time, the presence of legs or pseudopods, body armoring, and was positively correlated with growth, P:B ratio, ability to swim and a soft body. In other words, species with legs or prolegs that are able to move from leaf to leaf (to find water during dry periods or to seek for food) and resist desiccation thanks to their exoskeleton (e.g., Cyphon sp., E. bromeliarum) also have longer generation times and slower individual growth. Conversely, those soft-bodied species that are restricted to the water column (open-water swimmers, e.g., culicids) or live in fine detritus at the bottom of the well (e.g., chironomids) have shorter generation times and higher growth rates. The second axis was mainly defined by the annual production and mean annual biomass of species, suggesting that secondary production (Axis 2) is constrained by a trade-off between rapid growth, high biomass turnover and short generation time (Axis 1). Finally, the third axis was characterized by the respiration mode, trophic level, and, to a lesser extent, body size (Fig. 2).

\section{Broadening the scale: from individual bromeliads to forest plots}

Based on our results, an average $V$. splendens holding $234 \mathrm{ml}$ of water produced $149.24 \mathrm{mg}$ DM of invertebrates per year. After converting this estimate to the water surface area of a tank bromeliad, we obtain $23.93 \mathrm{~g} \mathrm{DM} \mathrm{m}^{-2}$ year $^{-1}$ (Fig. 3), a value that (on a per surface basis) falls above the median values of 5.0 and $14.8 \mathrm{~g} \mathrm{DM} \mathrm{m}^{-2}$ year $^{-1}$ for lakes and streams, respectively, and is even above the 80th and 70th percentiles for these systems. Note that these data are derived from studies mainly conducted in South-, Central- and North-America, Europe, and, to a lesser extent, in tropical and subtropical Asia (Fig. 3, Appendix S3). When restricting our comparisons to tropical streams (there were no tropical lakes) we found that the production of bromeliad invertebrates was above the resulting median $\left(4.7 \mathrm{~g} \mathrm{DM} \mathrm{m}^{-2}\right.$ year $^{-1}$ for all tropical streams; $N=7$; Fig. 3; Appendix S3). Our estimate was not significantly higher than the cumulative distribution of production estimates for all freshwaters, lakes, and streams ( $\mathrm{p}=0.59,0.77$, and 0.51 , respectively; Fig. 3). There were unfortunately not enough estimates to run these analyses for tropical streams. We further estimated that an average hectare of forest hosted 5,516.7 $\pm 942.2 \mathrm{~V}$. splendens, including 1,958.3 \pm 404.2 tankless individuals,

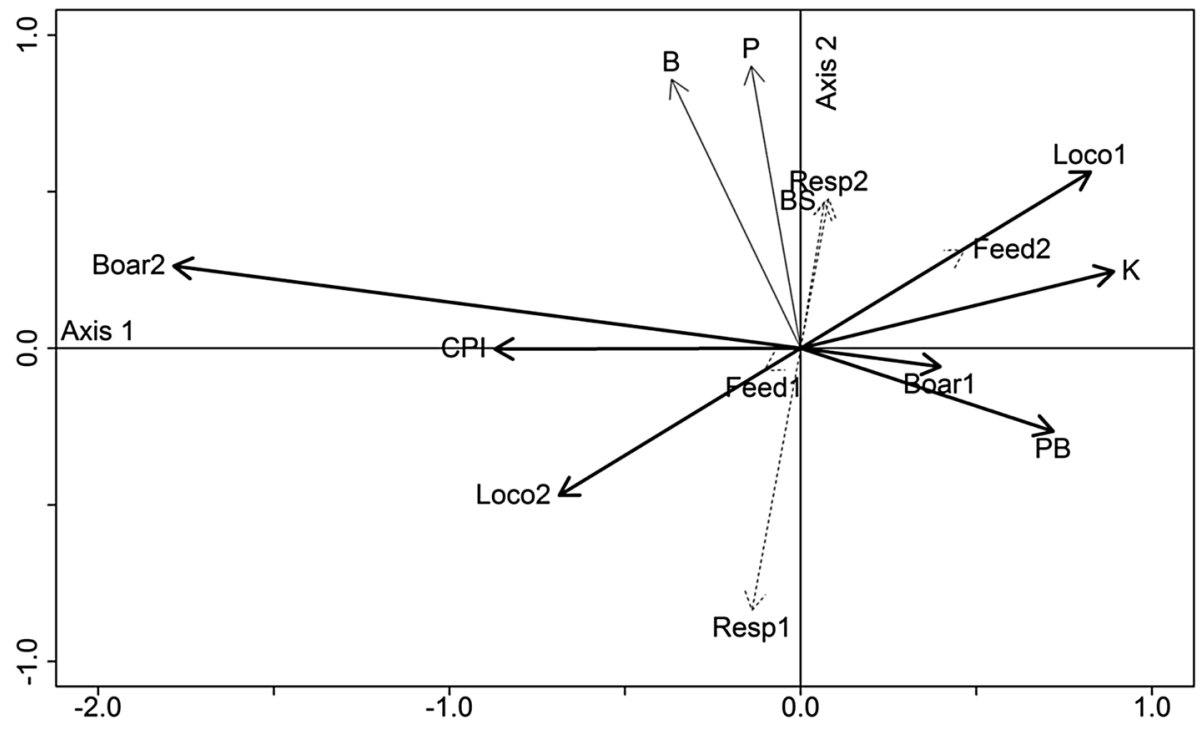

Fig. 2 Mixed Principal Component Analysis (mPCA) biplot showing correlations among production-related statistics and other functional traits. The directions of arrows show the gradients and correlations among variables, and length represents the strengths of variables in the ordination space. The thick, thin, and dotted arrows are correlated with the first, second, and third axes, respectively. Productionrelated statistics are: $k$ mean individual growth rate (\% per day), $C P I$ cohort production interval (days), $B$ mean annual biomass $\left(\mathrm{mg} \mathrm{ml}^{-1}\right)$, $P$ annual production $\left(\mathrm{mg} \mathrm{ml}^{-1}\right.$ year $\left.^{-1}\right), P: B$ biomass turnover rate. Other traits are: $\mathrm{BS}=$ maximum body size, locomotion mode (swimmer or crawler; Loco1 and Loco2), respiration mode (tegument/gills or plastron/siphon; Resp1 and Resp2), body armor (soft bodied or sclerotized/shell; Boar1 and Boar2), and trophic level (detritivore or predator; Feed1 and Feed2) 


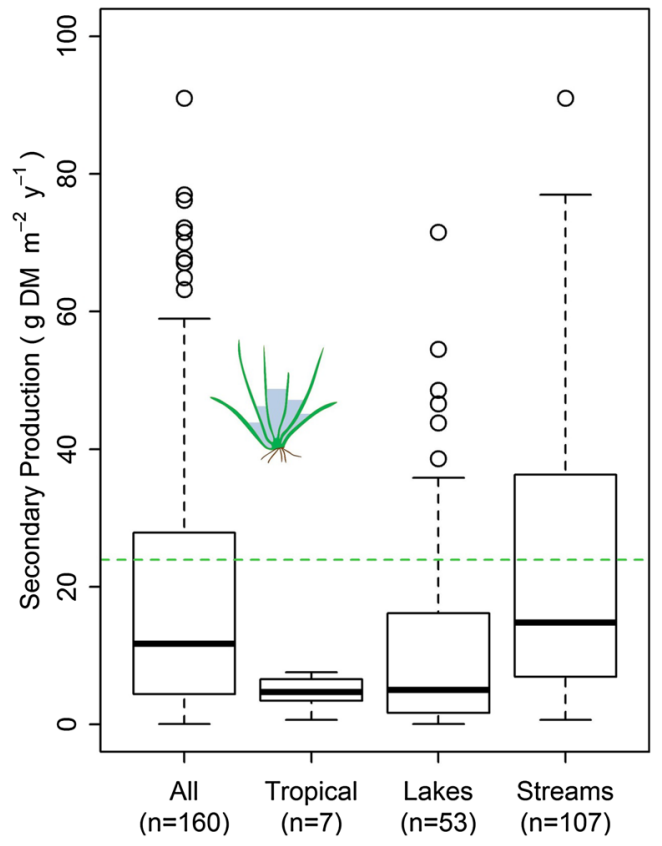

Fig. 3 Distribution of secondary production estimates (g Dry Mass $\mathrm{m}^{-2}$ year $^{-1}$ ) for all, tropical (there are no tropical lakes), lake and stream ecosystems, based on the literature (Appendix S3). The green dashed line indicates our estimate for aquatic invertebrates in an "average" tank bromeliad of the species Vriesea splendens. The most extreme outliers $\left(>100 \mathrm{~g} \mathrm{DM} \mathrm{m}^{-2} \mathrm{year}^{-1}\right)$ are not shown for display purposes (one value of $223.91 \mathrm{~g} \mathrm{DM} \mathrm{m}^{-2} \mathrm{y}^{-1}$ for lakes, and ten values ranging from 111.53 to $639.44 \mathrm{~g} \mathrm{DM} \mathrm{m}^{-2}$ year $^{-1}$ for streams)

$1,608.3 \pm 388.2$ "small" bromeliads, $1,116.7 \pm 218.1$ "medium" bromeliads, and $833.3 \pm 123.9$ "large" bromeliads. On average, these plants held $355 \pm 51.02 \mathrm{Ls}$ of water per hectare. When extrapolating to the total water volume impounded in these tank bromeliads, we obtained a secondary production of $226.8 \pm 32.5 \mathrm{~g} \mathrm{DM} \mathrm{ha}^{-1}$ year $^{-1}$ (mean $\pm \mathrm{SE}$; assuming non-significant changes in the bromeliad population over one year).

\section{Discussion}

Although the contribution of tank bromeliads (and likely phytotelmata in general) to invertebrate production at a forest scale depends on their density, individual plants sustain the production of a significant amount of invertebrate biomass per unit time relative to their size. On a per-surfacearea basis $\left(1 \mathrm{~m}^{2}\right)$, the secondary production of tank bromeliad invertebrates compares to that of other freshwater ecosystems worldwide. The production-related statistics of bromeliad invertebrates are fully integrated within trait syndromes of species that reflect how organisms interact with their environment. Together with other functional traits, production statistics may, therefore, help predicting changes in food-web structure and ecosystem function when species show turnover along environmental and/or biogeographic gradients.

\section{Secondary production and invertebrate traits}

Functional traits and production-related statistics revealed convergent life history strategies in phylogenetically distant species, here coleopterans, dipterans, crustaceans, and probably odonates (though individuals of the latter taxon were too scarce to obtain data on cohorts). We know that some bromeliad-dwelling invertebrates, notably Scirtidae (Cyphon sp.), and Tipulidae (Trentepohlia sp.), are able to move from leaf to leaf to find water (personal observations). Odonates (Coenagrionidae) can crawl on the aerial parts of bromeliads to find prey in other wells (Amundrud and Srivastava 2015). Mobility confers higher resistance to unsuitable conditions (e.g., drought) than physiological traits, because they trigger immediate responses (e.g., avoidance, mitigation, short range migrations). As a consequence, these species preferentially channel energy into the formation of biomass over longer time periods (lower growth and biomass turnover rates). Conversely, species that are confined to the epiphyte (here, to the tank) and have soft bodies (e.g., culicids, Corethrella sp.) are more sensitive to changes in food and habitat resources, and preferentially channel energy into fast larval growth and short hatching to emergence time (higher growth and biomass turnover rates). A related issue for future research is therefore to identify which environmental/anthropogenic factors increase the prevalence of certain trait syndromes within natural communities (Gamez-Virues et al. 2015).

\section{Secondary production and food webs}

At our study site, the trophic pyramid of bromeliad invertebrate was bottom-heavy, both in terms of production (87\%$13 \%$ for detritivores and predators, respectively) and mean annual biomass (90-10\%). The high production of detritivores thus clearly supported the production of the upper trophic level (amongst other source of nutrients such as terrestrial arthropods and feces; see Dézerald et al. 2014; Romero and Srivastava 2010). Overall, predator and prey species had similar biomass turnover ( $\mathrm{P}: \mathrm{B}$ ratios), and a few predators (e.g., Tanypodinae, Toxorhynchites haemorrhoidalis) had larger turnover than some of their prey (e.g., Culex stonei, Wyeomyia lamellata). This pattern is consistent with a numerical dominance of small-bodied predators with short generation times and a high number of generations per year in our study bromeliads (see Dézerald et al. 2017 for a detailed study of growth rates and developmental patterns of individual species). 
The relatively low contribution of shredders to the overall production of detritivores is a priori surprising. The detritus-based food webs of tank bromeliads mostly rely on the decomposition of leaf litter, and shredders that process the coarse detritus into smaller particles are supposedly the main bottom-up facilitators within the invertebrate community (but see Starzomski et al. 2010). The low contribution of shredders to the overall invertebrate community production in our bromeliads is however in line with recent studies showing that decomposition in tank bromeliads is essentially due to bacteria and fungi, and that microbial activity plays a key role in supporting the overall invertebrate production through facilitation of higher trophic levels (Leroy et al. 2017; Lecraw et al. 2017). This interpretation notably applies to French Guiana, where leaves are often rich in lignin and tannins (Coq et al. 2010), resulting in low palatability to aquatic invertebrates after senescence.

Although they contribute to secondary production, heterotrophic microorganisms (fungi, bacteria, heterotrophic protists) were not considered in this study. To the best of our knowledge, there has been no published study of the annual production of microorganisms in bromeliad ecosystems. Only a handful of studies have estimated bacterial production and biomass turnover in bromeliads, over short periods of time (a few hours; Haubrich et al. 2009; Marino et al. 2016, 2017). The bacterial production estimates in such studies varied from $3 \mathrm{e}-5$ to $2 \mathrm{e}-2 \mu \mathrm{g} \mathrm{C} \mathrm{ml}{ }^{-1} \mathrm{~h}^{-1}$, that is, from $3 \mathrm{e}-8$ to $2 \mathrm{e}-5 \mathrm{mg} \mathrm{DM} \mathrm{ml}^{-1} \mathrm{~h}^{-1}$. Assuming constant bacterial production over $8760 \mathrm{~h}$ in one year, the annual production of bacteria would range from $<0.01-21.6 \%$ of the total annual secondary production in bromeliads. In other words, heterotrophic microorganisms could represent a substantial fraction of the secondary production sustained by bromeliads.

\section{What drives secondary production in bromeliads?}

Secondary production and biomass turnover rates are thought to be influenced by the amount and quality of food at the base of aquatic food webs, temperature that affects the metabolic rate of ectotherms, the stability of environmental conditions, and species richness and/or species identity (Benke and Wallace 2014). Because the tank-bromeliad ecosystem is fueled by abundant leaf litter inputs in understories (Armbruster et al. 2002; Richardson et al. 2000a), we do not expect food to be a limiting factor. These allochtonous inputs support a "brown" food web (though light incidence can favour autochthonous primary production at some locations; see Brouard et al. (2012) and Farjalla et al. (2016), but the nutritional quality of detritus is often considered low compared to that of autochtonous primary production (Lau et al. 2014). Conversely, many lakes or mid-sized rivers have a significant autochtonous production that supports a "green" food web (e.g., Brett et al. 2017). Therefore, further estimates of secondary production in sun-exposed bromeliads would theoretically be needed to enhance the relevance of our comparisons among ecosystem types, taking into account the main source of energy that supports the food web.

Although daily to monthly variations in temperatures were low at our study site (Dézerald et al. 2017), high temperatures throughout the year (range from 20.5 to $33.5^{\circ} \mathrm{C}$ ) may potentially explain the high production estimates of bromeliad invertebrates. Accordingly, one may ask whether community-level production estimates follow latitudinal shifts in temperature gradients. The range of values we assembled for lakes and streams (Europe, North- and Central America, Asia; Neotropics to the Polar Circle) encompasses a wide range of geographic areas and thermal characteristics, and display a high variability (0.04-223.91 and 0.69-639.44 $\mathrm{g} \mathrm{DM} \mathrm{m}^{-2}$ year $^{-1}$ min-max for lakes and streams, respectively). We found, however, that northern temperate sites (e.g., North America, Europe; Appendix S3) exhibited some of the highest production estimates (be they ponds/lakes or streams/rivers), thus providing little support for a latitudinal gradient hypothesis. We acknowledge that in the absence of formal meta-analytical models, we cannot ascertain the relative importance of potential drivers of secondary production (resource quantity and quality, ecosystem size, species richness), but our attempt to compare secondary production estimates from different ecosystem types (bromeliads, lakes, streams) suggests interesting avenues for future theoretical research. Overall, our results indicate that (i) secondary production estimates in tank-bromeliads compare (on a per surface basis) to values reported for other freshwater ecosystems, and (ii) functional community composition (e.g., presence of large-bodied predators) account for differences in P:B and food-web structure in tank bromeliads (e.g., bottom- $v s$ top-heavy production pyramids). For instance, although odonates are often seen as the dominant top-predator in bromeliad ecosystems (Petermann et al. 2015), they are rare in the closed forests of French Guiana (see also Brouard et al. 2012) and their annual production was among the lowest estimations in our system.

\section{Does bromeliad invertebrate production matter in rainforests?}

We estimated that a hectare of forest at our site can produce up to $226.8 \mathrm{~g}$ DM of bromeliad invertebrates per year with a volume of 335 Ls of bromeliad-held water. Our study focused on the truly aquatic taxa of tank bromeliads, but terrestrial residents (and visitors) use these plants too as a source of nutrients, a permanent habitat, or a moist refuge (Gonçalves-Souza et al. 2010; Sabagh and Rocha 2014). We therefore believe that our conservative estimates of the secondary production sustained by individual bromeliads to 
bromeliad patches would be even higher if semi-aquatic and terrestrial metazoans were considered too. It is also worth noting that there was only one bromeliad species in the part of forest that formed our study site. We however know that many bromeliad species can co-occur at some sites in French Guiana and elsewhere (Poelman et al. 2013; Leroy et al. 2017). Some of these bromeliads (notably Aechmea spp.) are much larger in size and hold larger water volumes than $V$. splendens (e.g., up to $2 \mathrm{Ls}$ in Aechmea aquilega). In this case, one may expect that the contribution of bromeliads to forest-level secondary production is actually much higher than the one we estimated from a single bromeliad species.

The main caveat of our study is that we did not sample invertebrate communities by bromeliad size class. Only well-developed Vriesea splendens were sampled throughout the year. On one hand, this allowed us to maximize the number of individuals per species for subsequent measurements of body parts, and therefore, we obtained reliable descriptions of cohorts. On the other hand, one may argue that our estimate of secondary production primarily holds for an average bromeliad in the largest size class, so we might overestimate secondary production in smaller bromeliads of the forest. Our estimate of secondary production at the forest scale on a per milliliter basis however builds on the wellknown positive and linear relationship between invertebrate abundance and/or biomass and water volume in bromeliads (Armbruster et al. 2002; Marino et al. 2011; Dézerald et al. 2013; Petermann et al. 2015), and on our observation that most invertebrate species are usually found in all bromeliads at this site. Still, we acknowledge that a few species (particularly E. bromeliarum and Aulophorus superterrenus; $10 \%$ of the annual production in our bromeliad-level estimate) did not occur in the smallest tank-foming bromeliads (30\% of the total number of tank bromeliads, or $14 \%$ of the total water volume). It is therefore likely that our estimate of secondary production at the forest scale fall within an upper range. We however note that, if we combine the area of the tanks of the 833 individuals of the largest size class $(0.00624$ $\mathrm{m}^{2}$ ), we would end up with a total area of bromeliad tanks of $\sim 5.16 \mathrm{~m}^{2}$ just for these individuals. Therefore, if we consider just the largest plants, the corresponding secondary production would be concentrated in very small area from one hectare of forest $(<0.001 \%$ of the area), suggesting that tank bromeliads could be secondary production hot spots.

\section{Perspectives}

Cross-ecosystems fluxes of matter and energy at ecotones play a major role in the functioning of the adjacent ecosystem types (Baxter et al. 2005; Romero and Srivastava 2010; Wallace et al. 2015). Because most aquatic invertebrates in bromeliads are immature stages whereas the adult is terrestrial, it is likely that these epiphytes make a contribution to a broader segment of the forest food web. For instance, insect adults emerging from tank bromeliads are preyed on by spiders (Romero and Srivastava 2010). Although we did not quantify the amount of secondary production exported from tank bromeliads, amphibiotic insects, which represent $c a .90 \%$ of the mean annual production of the system, could attract a wide variety of terrestrial taxa foraging at ecotones. Where bromeliads occur at high densities, two-way interactions (processing of incoming detritus, exportation of insect biomass) may thus have a substantial impact on the whole ecosystem in terms of the pathways represented in the energy budget. Because tank bromeliads are conspicuous component of the neotropical flora, their ecological role in neotropical forest food webs could deserve relevant attention in the future. This issue remains unexplored, but could be addressed, for instance, by tracing the fate of nutrients from the bromeliad to the terrestrial food web and vice versa along biogeographic gradients of bromeliad density and trophic pyramid shape.

Acknowledgements We thank Frédéric Petitclerc, Clément Andrzejewski, Arthur Compin for field support, the Laboratoire Environnement Hydreco (Petit-Saut) for providing logistical support, Andrea Yockey-Dejean for proofreading the English text, and Andrew MacDonald for his comments on an advanced version of the manuscript. Two anonymous reviewers provided helpful comments on an earlier version of this paper.

Author contributions Wrote the paper: OD, RC, CL; designed and conceived the study: OD, RC, CL, BC, AD, ST; analyzed the data: OD, RC. All authors contributed to the interpretation of the results and conclusions. All co-authors have read the submitted version of the manuscript and approve its submission, and we confirm that all persons entitled to authorship have been so included.

Funding Financial support was provided by the Agence Nationale de la Recherche throught the Rainwebs project (grant ANR-12BSV7-0022-01) and an "Investissement d'Avenir" grant (Labex CEBA, ref. ANR-10-LABX-25-01). OD and ST were funded by a PhD scholarship (CNRS and the FSE for OD; Université de Guyane for ST).

\section{Compliance with ethical standards}

Conflict of interest The authors declare that they have no conflict of interest.

\section{References}

Amundrud SL, Srivastava DS (2015) Drought sensitivity predicts habitat size sensitivity in an aquatic ecosystem. Ecology 96:19571965. https://doi.org/10.1890/14-1828.1

Armbruster P, Hutchinson RA, Cotgreave P (2002) Factors influencing community structure in a South American tank bromeliad fauna. Oikos 96:225-234. https://doi. org/10.1034/j.1600-0706.2002.960204.x

Babler AL, Solomon CT, Schilke PR (2008) Depth-specific patterns of benthic secondary production in an oligotrophic lake. J N Am Benthol Soc 27:108-119. https://doi.org/10.1899/07-053.1 
Baxter CV, Fausch KD, Saunders WC (2005) Tangled webs: reciprocal flows of invertebrate prey link streams and riparian zones. Freshwat Biol 50:201-220

Benbow ME, Burky AJ, Way CM (2003) Life cycle of a torrenticolous Hawaiian chironomid (Telmatogeton torrenticola): stream flow and microhabitat effects. Annales de Limnologie-Int J Limnol 39:103-114. https://doi.org/10.1051/limn/2003008

Benke AC, Huryn AD (2010) Benthic invertebrate production-facilitating answers to ecological riddles in freshwater ecosystems. J N Am Benthol Soc 29:264-285. https://doi.org/10.1899/08-075.1

Benke AC, Wallace BJ (2014) High secondary production in a Coastal Plain river is dominated by snag invertebrates and fuelled mainly by amorphous detritus. Freshwat Biol 60:236-255. https://doi. org/10.1111/fwb.12460

Benke AC, Van Arsdall TC, Gillespie DM, Parrish FK (1984) Invertebrate productivity in a subtropical blackwater river: the importance of habitat and life history. Ecol Monogr 54:25-63. https:// doi.org/10.2307/1942455

Benzing DH (2000) Bromeliaceae: profile of an adaptive radiation. Cambridge University Press, Cambridge

Brett MT et al (2017) How important are terrestrial organic carbon inputs for secondary production in freshwater ecosystems? Freshwat Biol 62:833-853. https://doi.org/10.1111/fwb.12909

Brouard O, Céréghino R, Corbara B, Leroy C, Pélozuelo L, Dejean A, Carrias J-F (2012) Understorey environments influence functional diversity in tank-bromeliad ecosystems. Freshwat Biol 57:815823. https://doi.org/10.1111/j.1365-2427.2012.02749.x

Céréghino R et al (2011) Ant-plant mutualisms promote functional diversity in phytotelm communities. Funct Ecol 25:954-963. https://doi.org/10.1111/j.1365-2435.2011.01863.x

Chessel D, Dufour AB, Thioulouse J (2004) The ade4 package-I: one-table methods. R News 4:5-10

Coq S, Souquet J-M, Meudec E, Cheynier V, Hattenschwiler S (2010) Interspecific variation in leaf litter tannins drives decomposition in a tropical rain forest of French Guiana. Ecology 91:2080-2091. https://doi.org/10.1890/09-1076.1

Dézerald O, Leroy C, Corbara B, Carrias J-F, Pélozuelo L, Dejean A, Céréghino R (2013) Food-web structure in relation to environmental gradients and predator-prey ratios in tank-bromeliad ecosystems. Plos One 8:e71735. https://doi.org/10.1371/journal. pone. 0071735

Dézerald O, Talaga S, Leroy C, Carrias J-F, Corbara B, Dejean A, Céréghino R (2014) Environmental determinants of macroinvertebrate diversity in small water bodies: insights from tankbromeliads. Hydrobiologia 723:77-86. https://doi.org/10.1007/ s10750-013-1464-2

Dézerald O, Céréghino R, Corbara B, Dejean A, Leroy C (2015) Functional trait responses of aquatic macroinvertebrates to simulated drought in a Neotropical bromeliad ecosystem. Freshwat Biol 60:1917-1929. https://doi.org/10.1111/fwb.12621

Dézerald O, Leroy C, Corbara B, Dejean A, Talaga S, Céréghino R (2017) Environmental drivers of invertebrate population dynamics in Neotropical tank bromeliads. Freshwat Biol 62:229-242. https://doi.org/10.1111/fwb.12862

Farjalla VF et al (2016) Terrestrial support of aquatic food webs depends on light inputs: a geographically-replicated test using tank bromeliads. Ecology 97:2147-2156. https://doi.org/10.1002/ ecy. 1432

Frank JH, Lounibos LP (2009) Insects and allies associated with bromeliads: a review. Terrestrial Arthropod Rev 1:125-153. https:// doi.org/10.1163/187498308x414742

Gamez-Virues S et al. (2015) Landscape simplification filters species traits and drives biotic homogenization. Nature Commun. https:// doi.org/10.1038/ncomms9568

Givnish TJ et al (2011) Phylogeny, adaptive radiation, and historical biogeography in Bromeliaceae: insights from an eight-locus plastid phylogeny. Am J Bot 98:872-895. https:// doi.org/10.3732/ajb.1000059

Gonçalves-Souza T, Brescovit AD, Rossa-Feres DD, Romero GQ (2010) Bromeliads as biodiversity amplifiers and habitat segregation of spider communities in a Neotropical rainforest. J Arachnol 38:270-279

Gratton C, Vander Zanden MJ (2009) Flux of aquatic insect productivity to land: comparison of lentic and lotic ecosystems. Ecology 90:2689-2699. https://doi.org/10.1890/08-1546.1

Haubrich CS, Pires APF, Esteves FA, Farjalla VF (2009) Bottomup regulation of bacterial growth in tropical phytotelm bromeliads. Hydrobiologia 632:347-353. https://doi.org/10.1007/ s10750-009-9841-6

Huryn AD (1990) Growth and voltinism of lotic midge larvae - patterns across an Appalachian mountain basin. Limnol Oceanogr $35: 339-351$

Hynes HBN, Coleman MJ (1968) A simple method of assessing the annual production of stream benthos. Limnol Oceanogr 13:569-573. https://doi.org/10.4319/1o.1968.13.4.0569

Lau DCP, Sundh I, Vrede T, Pickova J, Goedkoop W (2014) Autochthonous resources are the main driver of consumer production in dystrophic boreal lakes. Ecology 95:1506-1519

Lecraw RM, Romero GQ, Srivastava DS (2017) Geographic shifts in the effects of habitat size on trophic structure and decomposition. Ecography 1-10. https://doi.org/10.1111/ecog.02796

Leroy C, Carrias J-F, Céréghino R, Corbara B (2016) The contribution of microorganisms and metazoans to mineral nutrition in bromeliads. J Plant Ecol 9:241-255. https://doi.org/10.1093/ jpe/rtv052

Leroy C, Corbara B, Dézerald O, Trzcinski MK, Carrias J-F, Dejean A, Céréghino R (2017) What drives detrital decomposition in neotropical tank bromeliads? Hydrobiologia. https://doi.org/10.1007/ s10750-017-3242-z

Marino NAC, Guariento RD, Dib V, Azevedo FD, Farjalla VF (2011) Habitat size determine algae biomass in tank-bromeliads. Hydrobiologia 678:191-199. https://doi.org/10.1007/ s10750-011-0848-4

Marino NAC, Srivastava DS, Farjalla VF (2016) Predator kairomones change food web structure and function, regardless of cues from consumed prey. Oikos 125:1017-1026. https://doi.org/10.1111/ oik.02664

Marino NAC et al (2017) Rainfall and hydrological stability alter the impact of top predators on food web structure and function. Glob Chang Biol 23:673-685. https://doi.org/10.1111/gcb.13399

Merritt RW, Cummins KW, Berg MB (2008) An introduction to aquatic insects of North America, 4th edn. Kendall/Hunt Publishing Company, Dubuque

Morin A, Mousseau TA, Roff DA (1987) Accuracy and precision of secondary production estimates. Limnol Oceanogr 32:1342-1352. https://doi.org/10.4319/lo.1987.32.6.1342

Ngai JT, Srivastava DS (2006) Predators accelerate nutrient cycling in a bromeliad ecosystem. Science 314:963. https://doi.org/10.1126/ science. 1132598

Perán A, Velasco J, Millán A (1999) Life cycle and secondary production of Caenis luctuosa (Ephemeroptera) in a semiarid stream (Southeast Spain). Hydrobiologia 400:187-194. https://doi.org/ 10.1023/a:1003717424687

Petermann JS et al (2015) Dominant predators mediate the impact of habitat size on trophic structure in bromeliad invertebrate communities. Ecology 96:428-439. https://doi.org/10.1890/14-0304.1

Pianka ER (1970) On r- and K-selection. Am Nat 105:592-597

Plante C, Downing JA (1989) Production of freshwater invertebrate populations in lakes. Can J Fish Aquat Sci 46:1489-1498

Poelman EH, van Wijngaarden RPA, Raaijmakers CE (2013) Amazon poison frogs (Ranitomeya amazonica) use different phytotelm characteristics to determine their suitability for egg and tadpole 
deposition. Evol Ecol 27:661-674. https://doi.org/10.1007/ s10682-013-9633-3

R Core Team (2015) R: a language and environment for statistical computing. R Foundation for Statistical Computing, Vienna, Austria

Richardson BA (1999) The bromeliad microcosm and the assessment of faunal diversity in a neotropical forest. Biotropica 31:321-336. https://doi.org/10.1111/j.1744-7429.1999.tb00144.x

Richardson BA, Richardson MJ, Scatena FN, McDowell WH (2000a) Effects of nutrient availability and other elevational changes on bromeliad populations and their invertebrate communities in a humid tropical forest in Puerto Rico. J Trop Ecol 16:167-188. https://doi.org/10.1017/s0266467400001346

Richardson BA, Rogers C, Richardson MJ (2000b) Nutrients, diversity, and community structure of two phytotelm systems in a lower montane forest, Puerto Rico. Ecol Entomol 25:348-356. https:// doi.org/10.1046/j.1365-2311.2000.00255.x

Richardson BA, Richardson MJ, Soto-Adames FN (2005) Separating the effects of forest type and elevation on the diversity of litter invertebrate communities in a humid tropical forest in Puerto Rico. J Anim Ecol 74:926-936. https://doi. org/10.1111/j.1365-2656.2005.00990.x
Romero GQ, Srivastava DS (2010) Food-web composition affects cross-ecosystem interactions and subsidies. J Anim Ecol 79:11221131. https://doi.org/10.1111/j.1365-2656.2010.01716.x

Sabagh LT, Rocha CFD (2014) Bromeliad treefrogs as phoretic hosts of ostracods. Naturwissenschaften 101:493-497

Starzomski BM, Suen D, Srivastava DS (2010) Predation and facilitation determine chironomid emergence in a bromeliad-insect food web. Ecol Entomol 35:53-60. https://doi. org/10.1111/j.1365-2311.2009.01155.x

Stead TK, Schmid-Araya JM, Hildrew AG (2005) Secondary production of a stream metazoan community: does the meiofauna make a difference? Limnol Oceanogr 50:398-403

Stork NE, Eggleton P (1992) Invertebrates as determinants and indicators of soil quality. Am J Alternative Agric 7:38-47. https://doi. org/10.1017/S0889189300004446 doi

Wallace JB, Eggert SL, Meyer JL, Webster JR (2015) Stream invertebrate productivity linked to forest subsidies: 37 stream-years of reference and experimental data. Ecology 96:1213-1228. https:// doi.org/10.1890/14-1589.1 